\title{
Morphology should not be forgotten in the era of genomics-a phylogenetic perspective
}

\section{Citation}

Giribet, Gonzalo. 2015. “Morphology Should Not Be Forgotten in the Era of Genomics-a Phylogenetic Perspective." Zoologischer Anzeiger - A Journal of Comparative Zoology (January). doi:10.1016/j.jcz.2015.01.003.

\section{Published Version}

doi:10.1016/j.jcz.2015.01.003

\section{Permanent link}

http://nrs.harvard.edu/urn-3:HUL.InstRepos:34609598

\section{Terms of Use}

This article was downloaded from Harvard University's DASH repository, and is made available under the terms and conditions applicable to Open Access Policy Articles, as set forth at http:// nrs.harvard.edu/urn-3:HUL.InstRepos:dash.current.terms-of-use\#OAP

\section{Share Your Story}

The Harvard community has made this article openly available.

Please share how this access benefits you. Submit a story.

\section{Accessibility}




\section{Morphology should not be forgotten in the era of}

\section{2 genomics - a phylogenetic perspective}

$4 \quad$ Gonzalo Giribet

5

6 Museum of Comparative Zoology, Department of Organismic and Evolutionary Biology, Harvard

7 University, 26 Oxford Street, Cambridge, MA 02138, USA 


\section{ABSTRACT}

10 Morphology has traditionally played a pivotal role in animal phylogeny since the first

11 evolutionary biologists began to decipher the animal tree of life. In recent times, however,

12 morphological characters have lost prominence in inferring deep relationships among

13 animals due to fundamental issues with homology statements and the choice of higher taxa

14 as terminals, but most importantly, due to declining costs of generating molecular data. As

15 genomes and transcriptomes become widely available, the burden of evidence for

16 morphology in overcoming molecular tree topologies has become ever heavier. In addition,

17 collection and coding of morphological characters must accelerate and become less

18 subjective. These needs have led to developments in the field of ontology, the use of a

19 controlled and formalized morphological vocabulary. Finally, the role of fossils for dating

20 molecular phylogenies is discussed. While molecules seem to have displaced morphology

21 for phylogenetic inference, the need to incorporate fossils as explicit terminals, including

22 dating of molecular-driven trees, together with new methods for high-throughput

23 morphological data acquisition and annotation, may rescue morphology to become again an

24 important player in phylogenetics. The reasons for maintaining a research program in

25 morphology are thus countless, as ultimately, a zoologist's interest is to understand form

26 and function, ecology and evolution, as well as all other aspects that may explain how our

27 favorite organisms live, behave and evolve.

28

29 Keywords: phylogenetics, phylogenomics, tip dating, node dating, total evidence dating 


\section{1. The historical role of morphology in systematics}

32

34 relationships, morphology has played a prominent role in elucidating the tree of life (e.g.,

35 Haeckel, 1866). With the advent of cladistics (phylogenetic systematics) (Hennig, 1950,

36 1966) and numerical methodologies (mostly parsimony-based methods), the prevalence of

37 explicit morphological data sets exploded in the 1980s and 1990s with the aim of testing

38 animal classification systems at various taxonomic levels. With respect to the

39 interrelationships of the animal phyla, several morphological data matrices were assembled

40 (e.g., Brusca and Brusca, 2003; Eernisse et al., 1992; Jenner, 2004; Jenner and Scholtz, 2005;

41 Meglitsch and Schram, 1991; Nielsen et al., 1996; Schram, 1991; Sørensen et al., 2000;

42 Zrzavý et al., 1998), some becoming the basis for subsequent combined analyses of

43 morphological and molecular data (e.g., Giribet et al., 2000; Glenner et al., 2004; Peterson

44 and Eernisse, 2001; Zrzavý et al., 1998).

45 The development of these matrices was however hampered by two methodological

46 impediments and few advances have been made since the early to mid-2000s. First, these

47 matrices often used higher taxa as terminals, a practice eloquently critiqued by Prendini

48 (2001), among other things by not allowing such higher taxa to be non-monophyletic. For

49 example, it is now broadly accepted that Acanthocephala nests within Rotifera (e.g., Garey

50 et al., 1996; Sørensen and Giribet, 2006; Wey-Fabrizius et al., 2014), something that could

51 never be discovered by coding Rotifera and Acanthocephala as terminals of their own - at

52 most one could place them as sister taxa. Second, many characters coded as absent/present

53 assumed homology of non-comparable conditions (this is independent from other issues

54 with applying a/p coding; see for example Pleijel, 1995), as critiqued by Jenner (2002). For 
55 example a character state such as presence of spiral cleavage bears a homology statement

56 (Hejnol, 2010), but its absence coding assumes that all other types of cleavage are

57 homologous - something that obviously is not the case. Many other issues with coding

58 characters and recycling data sets have also been exposed (e.g., Jenner, 2001).

59 While the use of species as terminals is a logical, albeit time consuming, solution to

60 the first problem - and may require coding multiple species with disparate morphologies

61 per phylum - resolving issues of homology can be complicated in many cases, especially

62 when dealing with complex characters such as egg cleavage patterns or segmentation

63 (Scholtz, 2002). Large morphological data matrices based on the exemplar approach

64 advocated by Prendini (2001) are occasionally assembled for many animal groups (e.g.,

65 Bieler et al., 2014; Lee et al., 2013). However, the exemplar approach has yet to be applied

66 to broad metazoan relationships, and few efforts seem to be currently directed that way.

\section{2. Molecular systematics in the era of genomics}

While morphological data sets played a pioneering role in elucidating the animal

72 phylogenetic tree, molecules entered the game relatively early (Field et al., 1988), and

73 included data from nearly all the animal phyla just a decade later (e.g., Giribet et al., 2000;

74 Zrzavý et al., 1998). But these phylogenies relied mostly on sequences from one or a few

75 genes obtained through Sanger sequencing of PCR (polymerase chain reaction)-amplified

76 fragments, even after the first invertebrate genomes were rapidly being sequenced and

77 assembled (Adams et al., 2000; Consortium, 1998). Sanger-based sequencing approaches

78 were however limited in the number of genes that could be amplified and they often lacked

79 signal in many deep nodes. Soon, with the availability of the first animal genomes, several 
80 data sets used information from 100 (Blair et al., 2002) to 3,000 gene sequences (Dopazo et

81 al., 2004). These data sets, severely limited in taxonomic scope, questioned what had

82 become recent "dogmas" of molecular phylogenetics, such as the clade Ecdysozoa (Philip et

83 al., 2005; Wolf et al., 2004). These studies however omitted most of the diversity of

84 invertebrates, save for a few model organisms for which genomes were available.

85 While these few genomes were available for a handful of model organisms,

86 generating whole genome data remained unreachable to the average systematist. The first

87 attempts to analyze large data sets using broad animal sampling efforts thus combined the

88 previous genomic data with a rapidly evolving set of multigene data sets derived from

89 expressed sequence tags (ESTs) (Delsuc et al., 2006; Delsuc et al., 2005; Lartillot and

90 Philippe, 2008; Philippe et al., 2007; Philippe et al., 2005; Philippe and Telford, 2006). Still,

91 these studies mostly relied on publicly available data until Dunn et al. (2008) published the

92 first comprehensive analysis of animal relationships using transcriptomics, soon expanded

93 to include a few additional missing species and key lineages like acoelomorphs and

94 placozoans (Hejnol et al., 2009). Many other analyses followed, especially re-evaluating the

95 base of the animal tree (e.g., Lartillot and Philippe, 2008; Moroz et al., 2014; Philippe et al.,

96 2009; Pick et al., 2010; Ryan et al., 2013), or some of its largest clades (e.g., Andrade et al.,

97 2014; Dordel et al., 2010; González et al., 2015; Kocot et al., 2011; Lemer et al., 2015;

98 Meusemann et al., 2010; Nesnidal et al., 2013; Philippe et al., 2011; Rehm et al., 2011; Rehm

99 et al., 2014; Sharma et al., 2014; Smith et al., 2011; Struck et al., 2014; von Reumont et al.,

100 2012; Weigert et al., 2014; Zapata et al., 2014). The newer analyses transitioned from small

101 and sparsely populated EST data matrices, generated by Sanger sequencing, to more

102 complete ones using genomes or transcriptomes obtained by 454 pyrosequencing, or

103 Illumina sequencing, among other techniques. These high-throughput sequencing

104 techniques have exploded, with an associated decrease in sequencing costs, shifting the 
105 paradigm of nucleic acid sequencing, and resulting in a low cost per base and a throughput

106 on the gigabase order of magnitude. Some phylogenetic studies therefore now include

107 thousands of genes-mostly protein-coding genes are used in phylogenomic studies—and

108 dozens of taxa, and larger data sets will soon be available (see several global initiatives in

109 Kumar et al., 2012; Lopez et al., 2014; Robinson et al., 2011). One such data set recently

110 explored the phylogeny of insects with an unprecedented amount of data (Misof et al.,

111 2014). The first multi-genome phylogeny of an animal group appeared more than half a

112 decade ago (Clark et al., 2007), and dozens of genomes can now be obtained for non-model

113 invertebrate species, as recently shown by the 101 genomes of the monarch butterfly

114 Danaus plexippus (Zhan et al., 2014). It is thus unavoidable that rapidly decreasing costs of

115 sequencing genomes coupled with analytical developments will result in sufficient data to

116 thoroughly examine many key nodes in the animal tree.

117 Whereas the available amounts of molecular data scale up faster than requisite

118 technological developments (i.e., computation power, algorithmic efficiency), the gradual

119 expansion of morphological data is far from paralleling the growth of molecular data

120 acquisition, in spite of more efficient data collection. This has led some to question whether

121 one should collect morphological data at all for the purpose of inferring phylogenies

122 (Scotland et al., 2003).

123

124

125 3. Why is it important to maintain a research program in morphology?

The reasons for maintaining a research program in morphology are countless, as

128 ultimately, a zoologist's interest is to understand form and function, ecology and evolution,

129 as well as all other aspects that may explain how our favorite organisms live, behave and 
130 evolve (see Richter and Wirkner, 2014). Put plainly, one's interest in animal phylogeny is

131 not the phylogeny per se, but to understand how the organisms evolve and adapt to their

132 environment, and how this reflects upon their morphology, ecology and behavior. And of

133 course, morphology will always be required for recognizing new taxa representing novel

134 body plans (e.g., Funch and Kristensen, 1995; Just et al., 2014; Kristensen, 1983; Kristensen

135 and Funch, 2000), "testing" molecular hypotheses, and to understand the evolution of body

136 plans (evo-devo). Therefore, rephrasing the title of this section, we may ask, "Why is it

137 important to maintain a research program in morphology for estimating phylogenies?",

138 especially when entire genomes can now be collected for hundreds of species. It is thus

139 unquestionable that large molecular data sets derived from next-generation sequencing

140 techniques are becoming available and the preferred way to infer the relationships of many

141 animal groups, including most phyla. It is also evident that cladistic matrices to infer deep

142 metazoan relationships are comparatively stagnant, given the amount of effort and

143 expertise required to code properly a matrix using an exemplar approach and produce

144 sound hypotheses of homology for animals that share few macroscopic features, such as

145 between for example the two "C. elegans", Crella, the sponge, and Caenorhabditis, the

146 nematode. There are obviously some sound alternatives to the exemplar approach

147 advocated here, such as combining actual observations from different exemplars for

148 analytical purposes, especially to minimize amounts of missing data, but still this strategy

149 does not seem to scale up with molecular data. Nevertheless, molecular hypotheses face the

150 insurmountable limitation of necessarily omitting vast amounts of biodiversity-those that

151 are extinct but still provide sound explanations of a group's phylogeny (Edgecombe, 2010).

152 Fossils constitute a key element for understanding the phylogenies of many animal

153 groups (Donoghue et al., 1989; Edgecombe, 2010; Wiens, 2004), from placental mammals

154 (O'Leary et al., 2013) to early panarthropods (Legg et al., 2013). In some cases, fossils in fact 
155 increase congruence between morphological and molecular phylogenies. The role of

156 morphology in coding fossil taxa for phylogenetic inference is thus undeniable and such

157 practice becomes a strong advocate (one of many) for maintaining a healthy program in

158 morphology. However, the proportion of phylogenies produced using fossils as terminals is

159 just a tiny fraction of the total number of phylogenies generated every year, as they require

160 expertise in more complex data than molecular phylogenies, and access to material often

161 not broadly available for study.

162 Another aspect worth exploring, but seldom touched upon in the literature, is the

163 information content of morphology and molecules, or even in some cases, that of the

164 different character systems. Some early studies compared measures such as the consistency

165 index of molecular and morphological data (Sanderson and Donoghue, 1989), but to my

166 knowledge, few invertebrate studies have focused on discerning the information content of

167 different systems. A seminal study by Harper et al. (2000) analyzed 43 anatomical and shell

168 characters in anomalodesmatan bivalves, and then re-analyzed 18 characters which could

169 be scored from shell characters alone-as many of these could also be scored for fossils.

170 They then showed conflict between the shell-based tree and the cladistic hypothesis based

171 on all the evidence (Harper et al., 2000). More recently, Bieler et al. (2014) analyzed

172 broader bivalve relationships using a combined approach with multiple molecular markers

173 and a specimen-based morphological approach of 210 characters (for a total of 22,680 cells

174 with $16.6 \%$ of missing data), and then assessed the phylogenetic signal of multiple

175 character systems. From the 210 characters, 99 had significant phylogenetic signal (when

176 compared to the molecular and total evidence results), but a few character systems,

177 including sperm ultrastructure and shell gross morphology and microstructure contained

178 above average signal, while other character systems, such as alimentary and gill characters,

179 are less informative than the average. Studies such as these can direct morphological 
180 research or even assess whether fossils would contribute with significant signal—as in this

181 case, two of the best character systems are available in the fossils. Analyses of phylogenetic

182 signal in morphological characters are however scarce, or in some cases, limited to just a

183 few characters to assess their possible value for inferring phylogenies (e.g., Gainett et al.,

184 2014). Further and rigorous assessment of the phylogenetic signal in morphological data is

185 certainly needed (see Wiens, 2004).

186 Another aspect to consider when relying on morphological data for inferring

187 phylogenetic relationships is the time of data collection and interpretation, an aspect that

188 has been properly outlined by just a few authors (e.g., Ramírez et al., 2007). Discussion has

189 emerged in the community about "high throughput morphology", and novel terms such as

190 "next-generation histology", or "phenomics", have appeared, often trailing on the newest

191 tendencies in molecular data generation. The use of automated methods for generating the

192 raw data that will be transformed into the comparative morphological data is becoming

193 more widespread, at least for technologies such as micro-computed tomography and

194 magnetic resonance imaging (e.g., Ziegler et al., 2011), leading to accelerated acquisition of

195 anatomical data (Ziegler, 2012; Ziegler et al., 2008; Ziegler and Menze, 2013). A major

196 impediment to the phylogenetic analysis of such data is the so-called linguistic problem of

197 morphology, or the translation of the anatomical raw data into anatomical descriptions, and

198 these into morphological data matrices (Vogt et al., 2010). A solution to this problem can be

199 provided by the development of ontologies-the use of a controlled and formalized

200 morphological vocabulary (e.g., Ramírez et al., 2007; Richter et al., 2010; Vogt et al., 2010;

201 Vogt et al., 2012; Vogt et al., 2013), but the practice and application of ontologies to

202 distantly related groups is difficult. Modernizing data collection, storage, display and

203 annotation are, together with the training of morphological experts who can interpret the

204 characters, key aspects for returning morphological data to a more prominent position in 
205 inferring phylogenetic patterns. However, there will always be a limiting step, character

206 conceptualization, that will require expert assessment and that will limit automated

207 procedures.

210 4. Morphology, fossils, dating, and phylogenomics

212 Dating trees has become common in systematics (Donoghue and Benton, 2007), as a

213 time-tree allows not only discussing patterns, but also tempo, of evolution, and thus allows

214 for testing specific hypotheses. The hypotheses often pertain to biogeography, and

215 increasingly to comparative methods evaluating diversification rates and alternative

216 models for evolutionary dynamics through time. Comparative methods are thus on the rise

217 (Harmon et al., 2008; Rabosky and Alfaro, 2010) and require both precise dating for testing

218 key innovations (Slater et al., 2012), where morphological or behavioral innovations cause

219 differential diversification rates (e.g., Dimitrov et al., 2012) and allow testing for adaptive

220 radiations, where niches are defined on the basis of morphology (e.g., Gillespie, 2004; Losos

221 and Ricklefs, 2009). It is thus ironic that fossils have become formidable allies of molecules

222 wherever inference of divergence times is required, while molecules have relegated

223 morphological characters of living organisms to an almost marginal role in phylogenetics.

224 For the most part, researchers use fossils to calibrate molecular trees, providing

225 information to constrain certain nodes (Donoghue and Benton, 2007). Some even explore

226 issues of uncertainty of calibrations and multiple models (e.g., Mao et al., 2012; Warnock et

227 al., 2012), but often assume that the taxonomy reflects the correct phylogenetic position of

228 the fossils, something difficult to justify without proper phylogenetic assessment. It is for

229 the latter reason that a minority of workers has opted to treat fossils as actual terminals 
230 (the so-called "tip dating" or "total evidence dating" approach), using morphological data to

231 infer fossil placement—as commonly done by paleontologists — while the molecular data

232 guides the dating (Murienne et al., 2010; Pyron, 2011; Sharma and Giribet, 2014; Wood et

233 al., 2013). Tip dating addresses on the one side the aspect of phylogenetic uncertainty of

234 fossils (see also Parham et al., 2012), but also the concern that the date estimates are more

235 accurate when fossils appear in a specific phylogenetic position, and not just as

236 approximate constraints to nodes (Pyron, 2011), especially when taxon sampling is limited.

237 This has been illustrated in a large arachnid data set with an exemplar fossil record (Sharma 238 and Giribet, 2014), and has now been tested with ancient DNA from fossil humans (Rieux et

239 al., 2014). The latter study, using a comprehensive data set of 350 ancient and modern

240 human complete mitochondrial DNA genomes, shows that for the same data set, estimates

241 based on individual dated tips are far more consistent with each other than those based on

242 node calibration, and should thus be considered as more reliable. This result thus provides

243 the scientific justification for preferring tip dating (using fossils as terminals) over node

244 dating (using fossils to constrain nodes), encouraging the use of tip dating whenever

245 possible-which may not always be possible.

246 There may also be other reasons for preferring tip versus node dating, these having

247 to do with the idiosyncrasies of the fossil record. Some groups (e.g., molluscs, arthropods,

248 brachiopods) fossilize well, while others (e.g., platyhelminths, nemerteans, rotifers) do not.

249 In addition, some geological periods have more rock available to us or more favorable

250 conditions for fossilization, so in some cases, a group that has missed a fossilization window

251 (e.g., in the Carboniferous) may not appear again until many millions of years later. To

252 provide an empirical example, the fossil record of Opiliones (harvestman arachnids) is

253 exceptional in many respects, with the first Devonian fossils (Dunlop et al., 2003) probably

254 close to the first appearance of this ancient arachnid order, with multiple lineages 
255 preserved as three-dimensional fossils in the Carboniferous (Garwood et al., 2011; Garwood

256 et al., 2014), and several other lineages known from the Mesozoic (see Dunlop, 2010 for a

257 recent review). The phylogeny of Opiliones is well understood (e.g., Giribet et al., 2002;

258 Giribet et al., 2010; Hedin et al., 2012a; Sharma et al., 2014; Shultz, 1998; Shultz and Regier,

259 2001), and while stem-group Eupnoi and Dyspnoi are known from the Paleozoic (Garwood

260 et al., 2011), the first fossil Cyphophthalmi is only from Cretaceous amber (Poinar, 2008),

261 between 45 and more than 300 million years after the diversification of the group

262 (following Sharma and Giribet, 2014), and its exact phylogenetic position is unclear. In the

263 case of Laniatores - the largest Opiliones suborder, which separated from its sister group

264 around the Devonian—the oldest known fossil is from Eocene Baltic amber (Ubick and

265 Dunlop, 2005). Therefore, while for some clades the first fossil occurs near their time of

266 origin and thus may provide good estimates of the age of a clade, in other cases the first

267 fossil occurrences may be closer to the tip than to the base of a clade. If the latter are used

268 for dating a clade, the excessively young fossil may produce a "push towards the present"

269 effect for the whole clade, and thus grossly underestimate the age of the clade in question

270 (Fig. 1).

271 It is clear that this may oversimplify the way node dating is done, as this fossil would

272 generally be treated as some sort of minimum age, but still, in the absence of much older

273 fossils in nearby clades, this effect should be noticeable. However, if the fossil were included

274 as a morphological terminal in a phylogeny instead of used for constraining a clade, its

275 position within the phylogeny should reflect its more derived position, and thus engender a

276 more precise dating of the whole clade. Of course one could argue that a more precise node

277 than "Cyphophthalmi" or "Laniatores" should be chosen when using those groups, but the

278 Burmese cyphophthalmid fossil was described in the wrong family and the phylogenetic

279 position of the Baltic fossils is difficult to ascertain without a comprehensive phylogenetic 
280 analysis of Laniatores, which was entirely lacking at the time of its description. One could

281 also argue that the taxonomy should be fixed first, but in the real world, molecular

282 systematists tend to follow the taxonomy from the taxonomists describing the fossils and

283 such fossils may often not be precisely positioned.

284 Another common problem of using fossils to date nodes is that sometimes such

285 nodes are misrepresented, because most authors "recycling" fossil papers for their analyses

286 without critical phylogenetic assessment tend to take conservative approaches. For

287 example, Hedin et al. (2012b) used the age estimate of two members of closely related

288 families of Eupnoi as the age for the entire suborder (see Sharma and Giribet, 2014),

289 resulting again in a push towards the present effect, but in this case for a different reason.

290 Had they coded the fossils as terminals, the two species represented molecularly would

291 have not been placed with the fossil they used for dating the node. A clear demonstration of

292 these was recently provided in two analyses of fossil Opiliones (Garwood et al., 2014;

293 Sharma and Giribet, 2014).

294 Tip dating however requires on the one hand morphological expertise, and also

295 algorithmic developments, as currently no software allows analyzing simultaneously

296 complex genomic-scale data (i.e., thousands of loci) and morphological data in a

297 probabilistic framework. To my knowledge, no software additionally enables efficient

298 dating using morphological and phylogenomic data matrices (see Sharma and Giribet,

299 2014). Due to the complexity of nucleotide and/or amino acid transition matrices, assigning

300 accurate models to simultaneous analyses of morphological and molecular sequence data is

301 inherently difficult, and recapitulates an older problem of how different data classes should

302 be weighted in total evidence analyses (Bull et al., 1993; Giribet, 2010; Kluge, 1989). 
308 phylogeny but recently have been replaced by molecular data due to multiple factors,

309 perhaps most prominently due to the efficiency and low cost of sequence data acquisition

310 and the development of analytical methods to deal with a vast amount of characters with a

311 small number of states. This is unfortunately leading to a large asymmetry in the amount of

312 studies using either type of data, while morphological data can still provide an important

313 framework to assess molecular trees-congruence between the two data sources generate

314 confidence in the results, while incongruence often leads to interesting aspects of body plan

315 evolution, including convergence. Several developments, including high throughput

316 morphological data collection and the establishment of clear ontologies are now required to

317 restore the place of morphology as a main player in elucidating phylogenetic relationships.

318 These will also aid in ameliorating previous problems with higher taxa as terminals and

319 poorly formulated homology statements. But most important is the need of using fossils to

320 improve phylogenetic inference and to help generate time-trees. In the latter arena, it is

321 beginning to become evident that tip dating (total evidence dating) may be philosophically

322 preferable to other forms of dating using fossils to calibrate accepted nodes. As refined

323 bioinformatic tools become available, it should be possible to analyze genomic and

324 morphological data in conjunction and to use these analyses for providing the most

325 accurate estimate of the timed phylogenies of a group. Molecular data may easily provide

326 the skeleton of the animal tree of life; morphology will still be required to test such skeleton,

327 to place key fossils, and to provide a sound temporal framework for such animal tree. 


\section{Acknowledgments}

330

331 This invited paper derived from the Presidential Lecture at III International

332 Congress on Invertebrate Morphology, and I am indebted to the organizers and the editors

333 of this volume for their invitation, especially to Gerhard Scholtz, Thomas Stach and Carsten

334 Lüter. Some of the ideas outlined here derive from many discussions and conversations

335 about total evidence, morphology, dating and genomics, I have had with many close

336 colleagues through the years, especially with Greg Edgecombe, Rosa Fernández, Gustavo

337 Hormiga, Prashant Sharma, Lars Vogt, and Ward Wheeler. Prashant Sharma, Rosa

338 Fernández, Stefan Richter and an anonymous reviewer provided comments and criticism

339 that helped to considerably improve this review. 
Adams, M.D., Celniker, S.E., Holt, R.A., Evans, C.A., Gocayne, J.D., Amanatides, P.G., Scherer, S.E., Li, P.W., Hoskins, R.A., Galle, R.F., George, R.A., Lewis, S.E., Richards, S., Ashburner, M., Henderson, S.N., Sutton, G.G., Wortman, J.R., Yandell, M.D., Zhang, Q., Chen, L.X., Brandon, R.C., Rogers, Y.H.C., Blazej, R.G., Champe, M., Pfeiffer, B.D., Wan, K.H., Doyle, C., Baxter, E.G., Helt, G., Nelson, C.R., Miklos, G.L.G., Abril, J.F., Agbayani, A., An, H.J., Andrews-Pfannkoch, C., Baldwin, D., Ballew, R.M., Basu, A., Baxendale, J., Bayraktaroglu, L., Beasley, E.M., Beeson, K.Y., Benos, P.V., Berman, B.P., Bhandari, D., Bolshakov, S., Borkova, D., Botchan, M.R., Bouck, J., Brokstein, P., Brottier, P., Burtis, K.C., Busam, D.A., Butler, H., Cadieu, E., Center, A., Chandra, I., Cherry, J.M., Cawley, S., Dahlke, C., Davenport, L.B., Davies, A., de Pablos, B., Delcher, A., Deng, Z.M., Mays, A.D., Dew, I., Dietz, S.M., Dodson, K., Doup, L.E., Downes, M., Dugan-Rocha, S., Dunkov, B.C., Dunn, P., Durbin, K.J., Evangelista, C.C., Ferraz, C., Ferriera, S., Fleischmann, W., Fosler, C., Gabrielian, A.E., Garg, N.S., Gelbart, W.M., Glasser, K., Glodek, A., Gong, F.C., Gorrell, J.H., Gu, Z.P., Guan, P., Harris, M., Harris, N.L., Harvey, D., Heiman, T.J., Hernandez, J.R., Houck, J., Hostin, D., Houston, D.A., Howland, T.J., Wei, M.H., Ibegwam, C., Jalali, M., Kalush, F., Karpen, G.H., Ke, Z.X., Kennison, J.A., Ketchum, K.A., Kimmel, B.E., Kodira, C.D., Kraft, C., Kravitz, S., Kulp, D., Lai, Z.W., Lasko, P., Lei, Y.D., Levitsky, A.A., Li, J.Y., Li, Z.Y., Liang, Y., Lin, X.Y., Liu, X.J., Mattei, B., McIntosh, T.C., McLeod, M.P., McPherson, D., Merkulov, G., Milshina, N.V., Mobarry, C., Morris, J., Moshrefi, A., Mount, S.M., Moy, M., Murphy, B., Murphy, L., Muzny, D.M., Nelson, D.L., Nelson, D.R., Nelson, K.A., Nixon, K., Nusskern, D.R., Pacleb, J.M., Palazzolo, M., Pittman, G.S., Pan, S., Pollard, J., Puri, V., Reese, M.G., Reinert, K., Remington, K., Saunders, R.D.C., Scheeler, F., Shen, H., Shue, B.C., Siden-Kiamos, I., Simpson, M., Skupski, M.P., Smith, T., Spier, E., Spradling, A.C., Stapleton, M., Strong, R., Sun, E., Svirskas, R., Tector, C., Turner, R., Venter, E., Wang, A.H.H., Wang, X., Wang, Z.Y., Wassarman, D.A., Weinstock, G.M., Weissenbach, J., Williams, S.M., Woodage, T., Worley, K.C., Wu, D., Yang, S., Yao, Q.A., Ye, J., Yeh, R.F., Zaveri, J.S., Zhan, M., Zhang, G.G., Zhao, Q., Zheng, L.S., Zheng, X.Q.H., Zhong, F.N., Zhong, W.Y., Zhou, X.J., Zhu, S.P., Zhu, X.H., Smith, H.O., Gibbs, R.A., Myers, E.W., Rubin, G.M., Venter, J.C., 2000. The genome sequence of Drosophila melanogaster. Science 287, 2185-2195. 
Andrade, S.C.S., Montenegro, H., Strand, M., Schwartz, M., Kajihara, H., Norenburg, J.L., Turbeville, J.M., Sundberg, P., Giribet, G., 2014. A transcriptomic approach to ribbon worm systematics (Nemertea): resolving the Pilidiophora problem. Mol. Biol. Evol. 31, 3206-3215.

Bieler, R., Mikkelsen, P.M., Collins, T.M., Glover, E.A., González, V.L., Graf, D.L., Harper, E.M., Healy, J.M., Kawauchi, G.Y., Sharma, P.P., Staubach, S., Strong, E.E., Taylor, J.D., Tëmkin, I., Zardus, J.D., Clark, S., Guzmán, A., McIntyre, E., Sharp, P., Giribet, G., 2014. Investigating the Bivalve Tree of Life - an exemplar-based approach combining molecular and novel morphological characters. Invertebr. Syst. 28, 32-115.

Blair, J.E., Ikeo, K., Gojobori, T., Hedges, S.B., 2002. The evolutionary position of nematodes. BMC Evol. Biol. 2, 1-7.

Brusca, R.C., Brusca, G.J., 2003. Invertebrates. 2nd Edition, 2nd ed. Sinauer Associates, Sunderland.

Bull, J.J., Huelsenbeck, J.P., Cunningham, C.W., Swofford, D.L., Waddell, P.J., 1993. Partitioning and combining data in phylogenetic analysis. Syst. Biol. 42, 384-397.

Clark, A.G., Eisen, M.B., Smith, D.R., Bergman, C.M., Oliver, B., Markow, T.A., Kaufman, T.C., Kellis, M., Gelbart, W., Iyer, V.N., Pollard, D.A., Sackton, T.B., Larracuente, A.M., Singh, N.D., Abad, J.P., Abt, D.N., Adryan, B., Aguade, M., Akashi, H., Anderson, W.W., Aquadro, C.F., Ardell, D.H., Arguello, R., Artieri, C.G., Barbash, D.A., Barker, D., Barsanti, P., Batterham, P., Batzoglou, S., Begun, D., Bhutkar, A., Blanco, E., Bosak, S.A., Bradley, R.K., Brand, A.D., Brent, M.R., Brooks, A.N., Brown, R.H., Butlin, R.K., Caggese, C., Calvi, B.R., Bernardo de Carvalho, A., Caspi, A., Castrezana, S., Celniker, S.E., Chang, J.L., Chapple, C., Chatterji, S., Chinwalla, A., Civetta, A., Clifton, S.W., Comeron, J.M., Costello, J.C., Coyne, J.A., Daub, J., David, R.G., Delcher, A.L., Delehaunty, K., Do, C.B., Ebling, H., Edwards, K., Eickbush, T., Evans, J.D., Filipski, A., Findeiss, S., Freyhult, E., Fulton, L., Fulton, R., Garcia, A.C., Gardiner, A., Garfield, D.A., Garvin, B.E., Gibson, G., Gilbert, D., Gnerre, S., Godfrey, J., Good, R., Gotea, V., Gravely, B., Greenberg, A.J., Griffiths-Jones, S., Gross, S., Guigo, R., Gustafson, E.A., Haerty, W., Hahn, M.W., Halligan, D.L., Halpern, A.L., Halter, G.M., Han, M.V., Heger, A., Hillier, L., Hinrichs, A.S., Holmes, I., Hoskins, R.A., Hubisz, M.J., Hultmark, D., Huntley, M.A., Jaffe, D.B., Jagadeeshan, S., Jeck, W.R., Johnson, J., Jones, C.D., Jordan, W.C., Karpen, G.H., Kataoka, E., Keightley, P.D., Kheradpour, P., Kirkness, E.F., Koerich, L.B., Kristiansen, K., Kudrna, D., Kulathinal, R.J., Kumar, S., Kwok, R., Lander, E., Langley, C.H., Lapoint, 
R., Lazzaro, B.P., Lee, S.J., Levesque, L., Li, R., Lin, C.F., Lin, M.F., Lindblad-Toh, K., Llopart, A., Long, M., Low, L., Lozovsky, E., Lu, J., Luo, M., Machado, C.A., Makalowski, W., Marzo, M., Matsuda, M., Matzkin, L., McAllister, B., McBride, C.S., McKernan, B., McKernan, K., Mendez-Lago, M., Minx, P., Mollenhauer, M.U., Montooth, K., Mount, S.M., Mu, X., Myers, E., Negre, B., Newfeld, S., Nielsen, R., Noor, M.A., O'Grady, P., Pachter, L., Papaceit, M., Parisi, M.J., Parisi, M., Parts, L., Pedersen, J.S., Pesole, G., Phillippy, A.M., Ponting, C.P., Pop, M., Porcelli, D., Powell, J.R., Prohaska, S., Pruitt, K., Puig, M., Quesneville, H., Ravi Ram, K., Rand, D., Rasmussen, M.D., Reed, L.K., Reenan, R., Reily, A., Remington, K.A., Rieger, T.T., Ritchie, M.G., Robin, C., Rogers, Y.H., Rohde, C., Rozas, J., Rubenfield, M.J., Ruiz, A., Russo, S., Salzberg, S.L., Sanchez-Gracia, A., Saranga, D.J., Sato, H., Schaeffer, S.W., Schatz, M.C., Schlenke, T., Schwartz, R., Segarra, C., Singh, R.S., Sirot, L., Sirota, M., Sisneros, N.B., Smith, C.D., Smith, T.F., Spieth, J., Stage, D.E., Stark, A., Stephan, W., Strausberg, R.L., Strempel, S., Sturgill, D., Sutton, G., Sutton, G.G., Tao, W., Teichmann, S., Tobari, Y.N., Tomimura, Y., Tsolas, J.M., Valente, V.L., Venter, E., Craig Venter, J., Vicario, S., Vieira, F.G., Vilella, A.J., Villasante, A., Walenz, B., Wang, J., Wasserman, M., Watts, T., Wilson, D., Wilson, R.K., Wing, R.A., Wolfner, M.F., Wong, A., Ka-Shu Wong, G., Wu, C.I., Wu, G., Yamamoto, D., Yang, H.P., Yang, S.P., Yorke, J.A., Yoshida, K., Zdobnov, E., Zhang, P., Zhang, Y., Zimin, A.V., Baldwin, J., Abdouelleil, A., Abdulkadir, J., Abebe, A., Abera, B., Abreu, J., Christophe Acer, S., Aftuck, L., Alexander, A., An, P., Anderson, E., Anderson, S., Arachi, H., Azer, M., Bachantsang, P., Barry, A., Bayul, T., Berlin, A., Bessette, D., Bloom, T., Blye, J., Boguslavskiy, L., Bonnet, C., Boukhgalter, B., Bourzgui, I., Brown, A., Cahill, P., Channer, S., Cheshatsang, Y., Chuda, L., Citroen, M., Collymore, A., Cooke, P., Costello, M., D'Aco, K., Daza, R., De Haan, G., Degray, S., Demaso, C., Dhargay, N., Dooley, K., Dooley, E., Doricent, M., Dorje, P., Dorjee, K., Dupes, A., Elong, R., Falk, J., Farina, A., Faro, S., Ferguson, D., Fisher, S., Foley, C.D., Franke, A., Friedrich, D., Gadbois, L., Gearin, G., Gearin, C.R., Giannoukos, G., Goode, T., Graham, J., Grandbois, E., Grewal, S., Gyaltsen, K., Hafez, N., Hagos, B., Hall, J., Henson, C., Hollinger, A., Honan, T., Huard, M.D., Hughes, L., Hurhula, B., Erii Husby, M., Kamat, A., Kanga, B., Kashin, S., Khazanovich, D., Kisner, P., Lance, K., Lara, M., Lee, W., Lennon, N., Letendre, F., Levine, R., Lipovsky, A., Liu, X., Liu, J., Liu, S., Lokyitsang, T., Lokyitsang, Y., Lubonja, R., Lui, A., Macdonald, P., Magnisalis, V., Maru, K., Matthews, C., McCusker, W., McDonough, S., Mehta, T., Meldrim, J., Meneus, L., Mihai, O., Mihalev, A., Mihova, T., 
Mittelman, R., Mlenga, V., Montmayeur, A., Mulrain, L., Navidi, A., Naylor, J., Negash, T., Nguyen, T., Nguyen, N., Nicol, R., Norbu, C., Norbu, N., Novod, N., O'Neill, B., Raghuraman, S., Rege, F., Reyes, R., Rise, C., Rogov, P., Ross, K., Ryan, E., Settipalli, S., Shea, T., Sherpa, N., Shi, L., Shih, D., Sparrow, T., Spaulding, J., Stalker, J., StangeThomann, N., Stavropoulos, S., Stone, C., Strader, C., Tesfaye, S., Thomson, T., Thoulutsang, Y., Thoulutsang, D., Topham, K., Topping, I., Tsamla, T., Vassiliev, H., Vo, A., Wangchuk, T., Wangdi, T., Weiand, M., Wilkinson, J., Wilson, A., Yadav, S., Young, G., Yu, Q., Zembek, L., Zhong, D., Zimmer, A., Zwirko, Z., Jaffe, D.B., Alvarez, P., Brockman, W., Butler, J., Chin, C., Gnerre, S., Grabherr, M., Kleber, M., Mauceli, E., Maccallum, I., 2007. Evolution of genes and genomes on the Drosophila phylogeny. Nature 450, 203-218.

Consortium, T.C.e.S., 1998. Genome sequence of the nematode C. elegans: A platform for investigating biology. Science 282, 2012-2018.

Delsuc, F., Brinkmann, H., Chourrout, D., Philippe, H., 2006. Tunicates and not cephalochordates are the closest living relatives of vertebrates. Nature 439, 965 968.

Delsuc, F., Brinkmann, H., Philippe, H., 2005. Phylogenomics and the reconstruction of the tree of life. Nat. Rev. Genet. 6, 361-375.

Dimitrov, D., Lopardo, L., Giribet, G., Arnedo, M.A., Álvarez-Padilla, F., Hormiga, G., 2012. Tangled in a sparse spider web: single origin of orb weavers and their spinning work unravelled by denser taxonomic sampling. P. Roy. Soc. B Biol. Sci. 279, 13411350.

Donoghue, M.J., Doyle, J.J., Gauthier, J., Kluge, A.G., Rowe, T., 1989. The importance of fossils in phylogeny reconstruction. Annu. Rev. Ecol. Syst. 20, 431-460.

Donoghue, P.C., Benton, M.J., 2007. Rocks and clocks: calibrating the Tree of Life using fossils and molecules. Trends Ecol. Evol. 22, 424-431.

Dopazo, H., Santoyo, J., Dopazo, J., 2004. Phylogenomics and the number of characters required for obtaining an accurate phylogeny of eukaryote model species. Bioinformatics 20 Suppl 1, I116-I121.

Dordel, J., Fisse, F., Purschke, G., Struck, T.H., 2010. Phylogenetic position of Sipuncula derived from multi-gene and phylogenomic data and its implication for the evolution of segmentation. J. Zool. Syst. Evol. Res. 48, 197-207. 
472 Dunlop, J.A., 2010. Geological history and phylogeny of Chelicerata. Arthropod Struct. Dev.

$473 \quad 39,124-142$.

474 Dunlop, J.A., Anderson, L.I., Kerp, H., Hass, H., 2003. Preserved organs of Devonian

475 harvestmen. Nature 425, 916.

476 Dunn, C.W., Hejnol, A., Matus, D.Q., Pang, K., Browne, W.E., Smith, S.A., Seaver, E.C., Rouse, G.W., Obst, M., Edgecombe, G.D., Sørensen, M.V., Haddock, S.H.D., Schmidt-Rhaesa, A., Okusu, A., Kristensen, R.M., Wheeler, W.C., Martindale, M.Q., Giribet, G., 2008. Broad phylogenomic sampling improves resolution of the animal tree of life. Nature 452, 745-749.

Edgecombe, G.D., 2010. Palaeomorphology: fossils and the inference of cladistic relationships. Acta Zool. 92, 72-80.

483 Eernisse, D.J., Albert, J.S., Anderson, F.E., 1992. Annelida and Arthropoda are not sister taxa:

484 A phylogenetic analysis of spiralian metazoan morphology. Syst. Biol. 41, 305-330.

485 Field, K.G., Olsen, G.J., Lane, D.J., Giovannoni, S.J., Ghiselin, M.T., Raff, E.C., Pace, N.R., Raff, R.A., 1988. Molecular phylogeny of the animal kingdom. Science 239, 748-753.

Funch, P., Kristensen, R.M., 1995. Cycliophora is a new phylum with affinities to Entoprocta and Ectoprocta. Nature 378, 711-714.

Gainett, G., Sharma, P.P., Pinto-da-Rocha, R., Giribet, G., Willemart, R.H., 2014. Walk it off: Predictive power of appendicular characters toward inference of higher-level relationships in Laniatores (Arachnida: Opiliones). Cladistics 30, 120-138.

492 Garey, J.R., Near, T.J., Nonnemacher, M.R., Nadler, S.A., 1996. Molecular evidence for 493 Acanthocephala as a subtaxon of Rotifera. J. Mol. Evol. 43, 287-292.

494 Garwood, R.J., Dunlop, J.A., Giribet, G., Sutton, M.D., 2011. Anatomically modern

495 Carboniferous harvestmen demonstrate early cladogenesis and stasis in opiliones.

$496 \quad$ Nature Comm. 2, 444.

497 Garwood, R.J., Sharma, P.P., Dunlop, J.A., Giribet, G., 2014. A new stem-group Palaeozoic

498 harvestman revealed through integration of phylogenetics and development. Curr. $499 \quad$ Biol. 24, 1-7.

500 Gillespie, R., 2004. Community assembly through adaptive radiation in Hawaiian spiders.

$501 \quad$ Science 303, 356-359.

502 Giribet, G., 2010. A new dimension in combining data? The use of morphology and

503 phylogenomic data in metazoan systematics. Acta Zool. 91, 11-19. 
504 Giribet, G., Distel, D.L., Polz, M., Sterrer, W., Wheeler, W.C., 2000. Triploblastic relationships

505 with emphasis on the acoelomates and the position of Gnathostomulida,

506

507 Cycliophora, Plathelminthes, and Chaetognatha: A combined approach of 18S rDNA sequences and morphology. Syst. Biol. 49, 539-562.

Giribet, G., Edgecombe, G.D., Wheeler, W.C., Babbitt, C., 2002. Phylogeny and systematic position of Opiliones: a combined analysis of chelicerate relationships using morphological and molecular data. Cladistics 18, 5-70.

511 Giribet, G., Vogt, L., Pérez González, A., Sharma, P., Kury, A.B., 2010. A multilocus approach to 512 harvestman (Arachnida: Opiliones) phylogeny with emphasis on biogeography and the systematics of Laniatores. Cladistics 26, 408-437.

514 Glenner, H., Hansen, A.J., Sørensen, M.V., Ronquist, F., Huelsenbeck, J.P., Willerslev, E., 2004. Bayesian inference of the metazoan phylogeny; a combined molecular and morphological approach. Curr. Biol. 14, 1644-1649.

González, V.L., Andrade, S.C.S., Bieler, R., Collins, T.M., Dunn, C.W., Mikkelsen, P.M., Taylor, J.D., Giribet, G., 2015. A phylogenetic backbone for Bivalvia: an RNA-seq approach. P. Roy. Soc. B Biol. Sci.

Haeckel, E., 1866. Generelle Morphologie der Organismen. Allgemeine Grundzüge der Organischen formen-wissenschaft, mechanisch begründet durch die von Charles Darwin reformirte descendenztheorie, 2 vols. Georg Reimer, Berlin.

Harmon, L.J., Weir, J.T., Brock, C.D., Glor, R.E., Challenger, W., 2008. GEIGER: investigating evolutionary radiations. Bioinformatics 24, 129-131.

Harper, E.M., Hide, E.A., Morton, B., 2000. Relationships between the extant Anomalodesmata: a cladistic test, in: Harper, E.M., Taylor, J.D., Crame, J.A. (Eds.), The

Hedin, M., Starrett, J., Akhter, S., Schönhofer, A.L., Shultz, J.W., 2012a. Phylogenomic Evolutionary Biology of the Bivalvia. The Geological Society of London, London, pp. resolution of Paleozoic divergences in harvestmen (Arachnida, Opiliones) via

532 Hedin, M., Tsurusaki, N., Macías-Ordóñez, R., Shultz, J.W., 2012b. Molecular systematics of sclerosomatid harvestmen (Opiliones, Phalangioidea, Sclerosomatidae): Geography

535 Hejnol, A., 2010. A twist in time-The evolution of spiral cleavage in the light of animal phylogeny. Integr. Comp. Biol. 50, 695-706. 
537 Hejnol, A., Obst, M., Stamatakis, A., M., O., Rouse, G.W., Edgecombe, G.D., Martinez, P., Baguñà, J., Bailly, X., Jondelius, U., Wiens, M., Müller, W.E.G., Seaver, E., Wheeler, W.C., Martindale, M.Q., Giribet, G., Dunn, C.W., 2009. Assessing the root of bilaterian

Hennig, W., 1950. Grundzüge einer Theorie der phylogenetischen Systematik. Deutsche Zentralverlag, Berlin.

544 Hennig, W., 1966. Phylogenetic Systematics, 1st ed. University of Illinois Press, Urbana.

545 Jenner, R.A., 2001. Bilaterian phylogeny and uncritical recycling of morphological data sets.

$546 \quad$ Syst. Biol. 50, 730-742.

547 Jenner, R.A., 2002. Boolean logic and character state identity: pitfalls of character coding in 548 metazoan cladistics. Contrib. Zool. 71, 67-91.

549 Jenner, R.A., 2004. Towards a phylogeny of the Metazoa: evaluating alternative phylogenetic positions of Platyhelminthes, Nemertea, and Gnathostomulida, with a critical reappraisal of cladistic characters. Contrib. Zool. 73, 3-163.

Jenner, R.A., Scholtz, G., 2005. Playing another round of metazoan phylogenetics: Historical epistemology, sensitivity analysis, and the position of Arthropoda within Metazoa on the basis of morphology, in: Koenemann, S., Jenner, R.A. (Eds.), Crustacean Issues 16: Crustacea and Arthropod Relationships. Festschrift for Frederick R. Schram. Taylor \& Francis, Boca Raton, pp. 355-385.

Just, J., Kristensen, R.M., Olesen, J., 2014. Dendrogramma, new genus, with two new nonbilaterian species from the marine bathyal of southeastern Australia (Animalia, Metazoa incertae sedis) - with similarities to some medusoids from the Precambrian Ediacara. PLoS ONE 9, e102976.

Kluge, A.G., 1989. A concern for evidence and a phylogenetic hypothesis of relationships among Epicrates (Boidae, Serpentes). Syst. Zool. 38, 7-25.

Kocot, K.M., Cannon, J.T., Todt, C., Citarella, M.R., Kohn, A.B., Meyer, A., Santos, S.R., Schander, C., Moroz, L.L., Lieb, B., Halanych, K.M., 2011. Phylogenomics reveals deep molluscan relationships. Nature 447, 452-456.

Kristensen, R.M., 1983. Loricifera, a new phylum with Aschelminthes characters from meiobenthos. Zeitschrift für zoologische Systematik und Evolutionsforschung 21, 163-180. 
Kristensen, R.M., Funch, P., 2000. Micrognathozoa: A new class with complicated jaws like those of Rotifera and Gnathostomulida. J. Morphol. 246, 1-49.

Kumar, S., Koutsovoulos, G., Kaur, G., Blaxter, M., 2012. Toward 959 nematode genomes. Worm 1, 42-50.

Lartillot, N., Philippe, H., 2008. Improvement of molecular phylogenetic inference and the phylogeny of Bilateria. Philos. T. R. Soc. Lon. B 363, 1463-1472.

Lee, M.S.Y., Soubrier, J., Edgecombe, G.D., 2013. Rates of phenotypic and genomic evolution during the Cambrian Explosion. Curr. Biol. 23, 1-7.

Legg, D.A., Sutton, M.D., Edgecombe, G.D., 2013. Arthropod fossil data increase congruence of morphological and molecular phylogenies. Nature Comm. 4, 2485.

Lemer, S., Kawauchi, G.Y., Andrade, S.C.S., González, V.L., Boyle, M.J., Giribet, G., 2015. Reevaluating the phylogeny of Sipuncula through transcriptomics. Mol. Phylogenet. Evol. 83, 174-183.

Lopez, J.V., Bracken-Grissom, H., Collins, A.G., Collins, T., Crandall, K., Distel, D., Dunn, C., Giribet, G., Haddock, S., Knowlton, N., Martindale, M., Medina, M., Messing, C., O’Brien, S.J., Paulay, G., Putnam, N., Ravasi, T., Rouse, G.W., Ryan, J.F., Schulze, A., Wörheide, G., Adamska, M., Bailly, X., Breinholt, J., Browne, W.E., Diaz, M.C., Evans, N., Flot, J.-F., Fogarty, N., Johnston, M., Kamel, B., Kawahara, A.Y., Laberge, T., Lavrov, D., Michonneau, F., Moroz, L.L., Oakley, T., Osborne, K., Pomponi, S.A., Rhodes, A., Rodriguez-Lanetty, M., Santos, S.R., Satoh, N., Thacker, R.W., Peer, Y.V.d., Voolstra, C.R., Welch, D.M., Winston, J., Zhou, X., 2014. The Global Invertebrate Genomics Alliance (GIGA): Developing community resources to study diverse invertebrate genomes. J. Hered. 105, 1-18.

Losos, J.B., Ricklefs, R.E., 2009. Adaptation and diversification on islands. Nature 457, 830836.

599 Meusemann, K., von Reumont, B.M., Simon, S., Roeding, F., Strauss, S., Kück, P., Ebersberger, 
601

602

603

604

605

606

607

608

609

610

611

612

613

614

615

616

617

618

619

620

621

622

623

624

625

626

627

628

629

630

631

632

H., Wägele, J.W., Misof, B., 2010. A phylogenomic approach to resolve the arthropod tree of life. Mol. Biol. Evol. 27, 2451-2464.

Misof, B., Liu, S., Meusemann, K., Peters, R.S., Donath, A., Mayer, C., Frandsen, P.B., Ware, J., Flouri, T., Beutel, R.G., Niehuis, O., Petersen, M., Izquierdo-Carrasco, F., Wappler, T., Rust, J., Aberer, A.J., Aspock, U., Aspock, H., Bartel, D., Blanke, A., Berger, S., Bohm, A., Buckley, T.R., Calcott, B., Chen, J., Friedrich, F., Fukui, M., Fujita, M., Greve, C., Grobe, P., Gu, S., Huang, Y., Jermiin, L.S., Kawahara, A.Y., Krogmann, L., Kubiak, M., Lanfear, R., Letsch, H., Li, Y., Li, Z., Li, J., Lu, H., Machida, R., Mashimo, Y., Kapli, P., McKenna, D.D., Meng, G., Nakagaki, Y., Navarrete-Heredia, J.L., Ott, M., Ou, Y., Pass, G., Podsiadlowski, L., Pohl, H., von Reumont, B.M., Schutte, K., Sekiya, K., Shimizu, S., Slipinski, A., Stamatakis, A., Song, W., Su, X., Szucsich, N.U., Tan, M., Tan, X., Tang, M., Tang, J., Timelthaler, G., Tomizuka, S., Trautwein, M., Tong, X., Uchifune, T., Walzl, M.G., Wiegmann, B.M., Wilbrandt, J., Wipfler, B., Wong, T.K.F., Wu, Q., Wu, G., Xie, Y., Yang, S., Yang, Q., Yeates, D.K., Yoshizawa, K., Zhang, Q., Zhang, R., Zhang, W., Zhang, Y., Zhao, J., Zhou, C., Zhou, L., Ziesmann, T., Zou, S., Li, Y., Xu, X., Zhang, Y., Yang, H., Wang, J., Wang, J., Kjer, K.M., Zhou, X., 2014. Phylogenomics resolves the timing and pattern of insect evolution. Science 346, 763-767.

Moroz, L.L., Kocot, K.M., Citarella, M.R., Dosung, S., Norekian, T.P., Povolotskaya, I.S., Grigorenko, A.P., Dailey, C., Berezikov, E., Buckley, K.M., Ptitsyn, A., Reshetov, D., Mukherjee, K., Moroz, T.P., Bobkova, Y., Yu, F., Kapitonov, V.V., Jurka, J., Bobkov, Y.V., Swore, J.J., Girardo, D.O., Fodor, A., Gusev, F., Sanford, R., Bruders, R., Kittler, E., Mills, C.E., Rast, J.P., Derelle, R., Solovyev, V.V., Kondrashov, F.A., Swalla, B.J., Sweedler, J.V., Rogaev, E.I., Halanych, K.M., Kohn, A.B., 2014. The ctenophore genome and the evolutionary origins of neural systems. Nature 510, 109-114.

Murienne, J., Edgecombe, G.D., Giribet, G., 2010. Including secondary structure, fossils and molecular dating in the centipede tree of life. Mol. Phylogenet. Evol. 57, 301-313.

Nesnidal, M.P., Helmkampf, M., Meyer, A., Witek, A., Bruchhaus, I., Ebersberger, I., Hankeln, T., Lieb, B., Struck, T.H., Hausdorf, B., 2013. New phylogenomic data support the monophyly of Lophophorata and an Ectoproct-Phoronid clade and indicate that Polyzoa and Kryptrochozoa are caused by systematic bias. BMC Evol. Biol. 13, 253. Nielsen, C., Scharff, N., Eibye-Jacobsen, D., 1996. Cladistic analyses of the animal kingdom. Biol. J. Linn. Soc. 57, 385-410. 
633 O'Leary, M.A., Bloch, J.I., Flynn, J.J., Gaudin, T.J., Giallombardo, A., Giannini, N.P., Goldberg, S.L., Kraatz, B.P., Luo, Z.X., Meng, J., Ni, X., Novacek, M.J., Perini, F.A., Randall, Z.S., Rougier, G.W., Sargis, E.J., Silcox, M.T., Simmons, N.B., Spaulding, M., Velazco, P.M.,

Parham, J.F., Donoghue, P.C.J., Bell, C.J., Calway, T.D., Head, J.J., Holroyd, P.A., Inoue, J.G., Irmis, R.B., Joyce, W.G., Ksepka, D.T., Patane, J.S.L., Smith, N.D., Tarver, J.E., van Tuinen, M., Yang, Z.H., Angielczyk, K.D., Greenwood, J.M., Hipsley, C.A., Jacobs, L., Makovicky, P.J., Muller, J., Smith, K.T., Theodor, J.M., Warnock, R.C.M., Benton, M.J., 2012. Best practices for justifying fossil calibrations. Syst. Biol. 61, 346-359.

Peterson, K.J., Eernisse, D.J., 2001. Animal phylogeny and the ancestry of bilaterians: inferences from morphology and 18S rDNA gene sequences. Evol. Dev. 3, 170-205.

Philip, G.K., Creevey, C.J., McInerney, J.O., 2005. The Opisthokonta and the Ecdysozoa may not be clades: stronger support for the grouping of plant and animal than for animal and fungi and stronger support for the Coelomata than Ecdysozoa. Mol. Biol. Evol.

Philippe, H., Brinkmann, H., Martinez, P., Riutort, M., Baguñà, J., 2007. Acoel flatworms are not Platyhelminthes: evidence from phylogenomics. PLoS ONE 2, e717.

654 Philippe, H., Derelle, R., Lopez, P., Pick, K., Borchiellini, C., Boury-Esnault, N., Vacelet, J., Renard, E., Houliston, E., Quéinnec, E., Da Silva, C., Wincker, P., Le Guyader, H., Leys, S., Jackson, D.J., Schreiber, F., Erpenbeck, D., Morgenstern, B., Wörheide, G., Manuel,

662 Philippe, H., Telford, M.J., 2006. Large-scale sequencing and the new animal phylogeny. Trends Ecol. Evol. 21, 614-620.

664 Pick, K.S., Philippe, H., Schreiber, F., Erpenbeck, D., Jackson, D.J., Wrede, P., Wiens, M., Alie, A., 665 Morgenstern, B., Manuel, M., Worheide, G., 2010. Improved phylogenomic taxon 
sampling noticeably affects nonbilaterian relationships. Mol. Biol. Evol. 27, 19831987.

668 Pleijel, F., 1995. On character coding for phylogeny reconstruction. Cladistics 11, 309-315.

669 Poinar, G., 2008. Palaeosiro burmanicum n. gen., n. sp., a fossil Cyphophthalmi (Arachnida: Opiliones: Sironidae) in Early Cretaceous Burmese amber, in: Makarov, S.E., Dimitrijevic, R.N. (Eds.), Advances in Arachnology and Developmental Biology. Papers dedicated to Prof. Dr. Bozidar Curcic. Faculty of Life Sciences, University of Vienna, and Serbian Academy of Sciences and Arts, Vienna, Belgrade, Sofia, pp. 267274.

Ramírez, M.J., Coddington, J.A., Maddison, W.P., Midford, P.E., Prendini, L., Miller, J., Griswold, C.E., Hormiga, G., Sierwald, P., Scharff, N., Benjamin, S.P., Wheeler, W.C., 2007. Linking of digital images to phylogenetic data matrices using a morphological ontology. Syst. Biol. 56, 283-294.

Rehm, P., Borner, J., Meusemann, K., von Reumont, B.M., Simon, S., Hadrys, H., Misof, B., Burmester, T., 2011. Dating the arthropod tree based on large-scale transcriptome data. Mol. Phylogenet. Evol. 61, 880-887.

Richter, S., Loesel, R., Purschke, G., Schmidt-Rhaesa, A., Scholtz, G., Stach, T., Vogt, L., Wanninger, A., Brenneis, G., Doring, C., Faller, S., Fritsch, M., Grobe, P., Heuer, C.M., Kaul, S., Møller, O.S., Müller, C.H.G., Rieger, V., Rothe, B.H., Stegner, M.E.J., Harzsch, S., 2010. Invertebrate neurophylogeny: suggested terms and definitions for a neuroanatomical glossary. Front. Zool. 7, 29.

Richter, S., Wirkner, C.S., 2014. A research program for Evolutionary Morphology. J. Zool. Syst. Evol. Res. 52, 338-350. 
Rieux, A., Eriksson, A., Li, M., Sobkowiak, B., Weinert, L.A., Warmuth, V., Ruiz-Linares, A., Manica, A., Balloux, F., 2014. Improved calibration of the human mitochondrial clock using ancient genomes. Mol. Biol. Evol. 31, 2780-2792.

Robinson, G.E., Hackett, K.J., Purcell-Miramontes, M., Brown, S.J., Evans, J.D., Goldsmith, M.R., Lawson, D., Okamuro, J., Robertson, H.M., Schneider, D.J., 2011. Creating a buzz about insect genomes. Science 331, 1386.

Ryan, J.F., Pang, K., Schnitzler, C.E., Nguyen, A.D., Moreland, R.T., Simmons, D.K., Koch, B.J., Francis, W.R., Havlak, P., Smith, S.A., Putnam, N.H., Haddock, S.H.D., Dunn, C.W., Wolfsberg, T.G., Mullikin, J.C., Martindale, M.Q., Baxevanis, A.D., 2013. The genome of

Sanderson, M.J., Donoghue, M.J., 1989. Patterns of variation in levels of homoplasy. the ctenophore Mnemiopsis leidyi and its implications for cell type evolution. Science

Scholtz, G., 2002. The Articulata hypothesis - or what is a segment? Org. Divers. Evol. 2, 197215.

Schram, F.R., 1991. Cladistic analysis of metazoan phyla and the placement of fossil problematica, in: Simonetta, A.M., Conway Morris, S. (Eds.), The early evolution of Metazoa and the significance of problematic taxa, 1 ed. Cambridge University Press, Cambridge, pp. 35-46.

Scotland, R.W., Olmstead, R.G., Bennett, J.R., 2003. Phylogeny reconstruction: the role of morphology. Syst. Biol. 52, 539-548.

Sharma, P.P., Giribet, G., 2014. A revised dated phylogeny of the arachnid order Opiliones. Front. Genet. 5, 255.

Sharma, P.P., Kaluziak, S., Pérez-Porro, A.R., González, V.L., Hormiga, G., Wheeler, W.C., Giribet, G., 2014. Phylogenomic interrogation of Arachnida reveals systemic conflicts in phylogenetic signal. Mol. Biol. Evol. 31, 2963-2984.

730 Slater, G.J., Harmon, L.J., Alfaro, M.E., 2012. Integrating fossils with molecular phylogenies improves inference of trait evolution. Evolution 66, 3931-3944. 
Smith, S., Wilson, N.G., Goetz, F., Feehery, C., Andrade, S.C.S., Rouse, G.W., Giribet, G., Dunn, C.W., 2011. Resolving the evolutionary relationships of molluscs with phylogenomic tools. Nature 480, 364-367.

Sørensen, M.V., Funch, P., Willerslev, E., Hansen, A.J., Olesen, J., 2000. On the phylogeny of

Sørensen, M.V., Giribet, G., 2006. A modern approach to rotiferan phylogeny: Combining morphological and molecular data. Mol. Phylogenet. Evol. 40, 585-608.

Struck, T.H., Wey-Fabrizius, A.R., Golombek, A., Hering, L., Weigert, A., Bleidorn, C., Klebow, S., Iakovenko, N., Hausdorf, B., Petersen, M., Kück, P., Herlyn, H., Hankeln, T., 2014. Platyzoan paraphyly based on phylogenomic data supports a non-coelomate ancestry of Spiralia. Mol. Biol. Evol. 31, 1833-1849.

Ubick, D., Dunlop, J.A., 2005. On the placement of the Baltic amber harvestman Gonyleptes nemastomoides Koch \& Berendt, 1854, with notes on the phylogeny of Cladonychiidae (Opiliones, Laniatores, Travunioidea). Mitt. Mus. Nat.kd. Berl., Geowiss. Reihe 8, 75-82.

Vogt, L., Bartolomaeus, T., Giribet, G., 2010. The linguistic problem of morphology: Structure versus homology and the standardization of morphological data. Cladistics 26, 301325.

Vogt, L., Nickel, M., Jenner, R.A., Deans, A.R., 2013. The need for data standards in zoomorphology. J. Morphol. 274, 793-808.

von Reumont, B.M., Jenner, R.A., Wills, M.A., Dell'Ampio, E., Pass, G., Ebersberger, I., Meyer, B., Koenemann, S., Iliffe, T.M., Stamatakis, A., Niehuis, O., Meusemann, K., Misof, B., molecular clock. Biol Lett 8, 156-159.

761 Weigert, A., Helm, C., Meyer, M., Nickel, B., Arendt, D., Hausdorf, B., Santos, S.R., Halanych, annelid tree using transcriptomics. Mol. Biol. Evol. 31, 1391-1401. 
764 Wey-Fabrizius, A.R., Herlyn, H., Rieger, B., Rosenkranz, D., Witek, A., Mark Welch, D.B., Ebersberger, I., Hankeln, T., 2014. Transcriptome data reveal syndermatan relationships and suggest the evolution of endoparasitism in Acanthocephala via an epizoic stage. PLoS One 9, e88618.

Wiens, J.J., 2004. The role of morphological data in phylogeny reconstruction. Syst. Biol. 53, 653-661.

Wolf, Y.I., Rogozin, I.B., Koonin, E.V., 2004. Coelomata and not Ecdysozoa: evidence from genome-wide phylogenetic analysis. Genome Res. 14, 29-36.

772 Wood, H.M., Matzke, N.J., Gillespie, R.G., Griswold, C.E., 2013. Treating fossils as terminal taxa in divergence time estimation reveals ancient vicariance patterns in the palpimanoid spiders. Syst. Biol. 62, 264-284.

Zapata, F., Wilson, N.G., Howison, M., Andrade, S.C.S., Jörger, K.M., Schrödl, M., Goetz, F.E., Giribet, G., Dunn, C.W., 2014. Phylogenomic analyses of deep gastropod relationships reject Orthogastropoda. P. Roy. Soc. B Biol. Sci. 281, 20141739.

Zhan, S., Zhang, W., Niitepõld, K., Hsu, J., Fernández Haeger, J., Zalucki, M.P., Altizer, S., de Roode, J.C., Reppert, S.M., Kronforst, M.R., 2014. The genetics of monarch butterfly migration and warning colouration. Nature 514, 317-321.

Ziegler, A., 2012. Broad application of non-invasive imaging techniques to echinoids and other echinoderm taxa. Zoosymposia 7, 53-70.

Ziegler, A., Faber, C., Mueller, S., Bartolomaeus, T., 2008. Systematic comparison and reconstruction of sea urchin (Echinoidea) internal anatomy: a novel approach using magnetic resonance imaging. BMC Biol. 6, 33.

Ziegler, A., Kunth, M., Mueller, S., Bock, C., Pohmann, R., Schröder, L., Faber, C., Giribet, G., 2011. Application of magnetic resonance imaging in zoology. Zoomorphology 130, 227-254. on morphological and 18S ribosomal DNA evidence. Cladistics 14, 249-285. 
795 Fig. 1. Effect of a young fossil on the phylogeny of an old lineage, represented in this case by

796 an amber fossil for a clade with an old history (A). Supposing that the fossil could be

797 assigned to the red clade, based on morphology, it could be used for tip dating (B) or for

798 constraining a node (C). In tip dating, the clade could accommodate for extensive

799 cladogenesis occurring prior to the fossil, if the fossil were positioned in a derived position

800 in the phylogeny of the group. In node dating, the fossil may cause a "push towards the 801 present" effect. See text for discussion. 